\title{
EFEKTIVITAS PAJAK PROGRESIF KENDARAAN RODA DUA PADA SISTEM ADMINISTRASI MANUNGGAL SATU ATAP (SAMSAT) DI WILAYAH BOGOR
}

\section{EFFECTIVENESS OF TWO-WHEELED VEHICLE'S PROGRESSIVE TAX ON ONE ROOF SYSTEM MANAGEMENT IN REGION OF BOGOR}

\author{
Jifly Zulfahmi Adam dan \\ T. N. Syamsah
}

\author{
Program Studi Ilmu Hukum Sekolah Pascasarjana \\ Universitas Djuanda Bogor \\ Jl. Tol Ciawi No. 1, Kotak Pos 35, Bogor 16720. \\ Korespondensi : Jifly Zulfahmi A, Telp. - \\ e-mail : -
}

\begin{abstract}
Jurnal Living Law, Vol. 10, No.

1,

2018

hlm. 45-57

Abstract : Identification of this research are1) How is the progressive tax's effectiveness of two-wheeled vehicles in the Bogor Region's Samsat? 2) What are the obstacles and efforts made by the regional government to overcome the implementation of progressive taxes? 3) What is the solution to implementing a fair progressive tax between the government and taxpayers?. The research method used in this research is the normative juridical approach, namely the law is conceptualized as norms, rules, principles or dogmas/jurisprudence. The result of this research are: 1) implementation of progressive tax of two-wheeled vehicle at Samsat City Bogor and Bogor Regency not yet optimal; 2) Inhibiting factors that occur in the implementation of progressive tax on motorcycle taxpayers include: Inhibiting factors for officers in the field, facilities and infrastructure factors, community factors as taxpayers; 3) Solutions are given to overcome the inhibiting factors, namely: Adding facilities and infrastructure in the form of samsat corner in the mall, samsat to pick up the ball with samsat around, Samsat City Office Bogor and Bogor regency also facilitate taxpayers who do report on the sale of vehicles motor that has been sold for the taxpayer is not subject to progressive tax.
\end{abstract}

Keywords : Progressive Tax, One Roof System, Two-Wheeled Vehicle.

\begin{abstract}
Abstrak : Identifikasi penelitian ini yaitu: 1) Bagaimana efektifitas pajak progresif kendaraan roda dua pada Samsat Wilayah Bogor? 2) Apa kendala dan upaya yang dilakukan pemerintah daerah untuk mengatasi penerapan pajak progresif tersebut? 3) Bagaimana solusi penerapan pajak progresif yang adil antara pemerintah dan wajib pajak? Metode penelitian yang digunakan dalam penelitian ini adalah pendekatan yuridis normative. Hasil dari penelitian ini yaitu: 1) pelaksanaan penerapan pajak progresif kendaraan roda dua pada Samsat Kota Bogor dan Kabupaten Bogor belum optimal; 2) Faktor penghambat yang terjadi dalam penerapan pajak progresif terhadap wajib pajak kendaraan bermotor antara lain: Faktor penghambat bagi petugas di lapangan, faktor sarana dan prasarana, faktor masyarakat sebagai wajib pajak; 3) Solusi yang diberikan untuk mengatasi faktor penghambat tersebut, yaitu: Menambah sarana dan prasarana berupa samsat corner yang berada di mall, samsat melakukan jemput bola dengan samsat keliling, Kantor Samsat Kota Bogor dan Kabupaten Bogor juga mempermudah wajib pajak yang melakukan lapor jual terhadap kendaraan bermotor yang telah dijualnya agar wajib pajak tersebut tidak terkena pajak progresif.
\end{abstract}

Kata Kunci : Pajak Progresif, SAMSAT, Kendaraan Roda Dua. 


\section{PENDAHULUAN}

Perumahan dan pemukiman Sebagaimana diuraikan dalam Pembukaan Undang-Undang Dasar 1945, bahwa tujuan negara Republik Indonesia adalah "Untuk memajukan kesejahteraan umum, mencerdaskan kehidupan Bangsa, dan ikut melaksanakan ketertiban dunia berdasarkan kemerdekaan, perdamaian abadi, dan keadilan sosial“. Untuk dapat mewujudkan tujuan negara tersebut, negara memfasilitasinya melalui upayaupaya sejalan dengan tugas pokok dan fungsinya.

Pembangunan Nasional sebagai pengamalan Pancasila dilaksanakan secara bertahap dan berkesinambungan, yang bertujuan untuk mewujudkan suatu masyarakat yang adil dan sejahtera. Agar tujuan pembangunan nasional tersebut dapat terwujud dibutuhkan pembiayaan yang jumlahnya dari waktu ke waktu semakin meningkat. Hal ini disebabkan oleh pembangunan itu sendiri yaitu semakin membutuhkan biaya yang besar. ${ }^{1}$

Di Indonesia, hukum berperan sebagai sarana pembangunan, yaitu bahwa hukum harus mampu memenuhi kebutuhan sesuai dengan tingkat kemajuan serta tahapan pembangunan di segala bidang, sehingga dapat diciptakan ketertiban dan kepastian hukum untuk menjamin serta memperlancar pelaksanaan pembangunan. $^{2}$

Pada saat ini sebagai negara berkembang Indonesia tengah gencargencarnya melaksanakan pembangunan disegala bidang baik ekonomi, sosial, politik, hukum, maupun bidang pendidikan dengan tujuan untuk meningkatkan kesejahteraan rakyat, mencerdaskan kehidupan bangsa dengan adil dan makmur. Untuk mewujudkan tujuan dari pembangunan tersebut, setiap negara harus memperhatikan masalah

\footnotetext{
1 Syamsah, T.N., Kedudukan Pengadilan Pajak Dihubungkan Dengan Sistem Peradilan di Indonesia, Cetakan Pertama, Bogor: Unida Press, 2010, HIm. 23.

2 Ibid., Hlm. 7.
}

pembiayaan. Salah satu usaha yang harus ditempuh pemerintah dalam mendapatkan pembiayaan yaitu dengan memaksimalkan potensi pendapatan yang berasal dari Negara Indonesia sendiri, salah satunya berasal dari pajak.

Di Indonesia, salah satu penerimaan negara yang sangat penting adalah pajak. Pajak merupakan alat bagi pemerintah dalam mencapai tujuan untuk mendapatkan penerimaan baik yang bersifat langsung maupun tidak langsung untuk membiayai pengeluaran rutin serta pembangunan nasional dan ekonomi masyarakat. Pajak adalah iuran rakyat kepada kas negara yang tidak mendapat imbalan secara langsung.

Pajak sendiri menurut pemungutan dan pengelolaannya dibagi menjadi dua yaitu pajak pusat dan pajak daerah. Pajak pusat memiliki delapan jenis pajak. Sedangkan, pajak daerah memiliki sepuluh jenis pajak dimana pajak tersebut dibagi menjadi empat pajak provinsi dan enam pajak kabupaten/kota. ${ }^{3}$

Pajak daerah merupakan sumber pendapatan yang paling tinggi, karena pendapatan tersebut digunakan untuk membiayai penyelenggaraan pemerintah dan pembangunan daerah. Daerah memiliki wewenang untuk mengatur wilayah dan mengembangkan segala potensi yang dimiliki, sehingga kewenangan ini akan mendorong daerah untuk berkembang secara kompetitif yang sehat dengan memanfaatkan semaksimal mungkin sumber daya yang dimiliki. Dari sumber daya yang dimiliki sebagai sumber pendapatan sebagian besar berasal dari pajak kendaraan bermotor.

Pajak Kendaraan Bermotor (PKB) memiliki peranan penting bagi pendapatan daerah, karena memberi kontribusi yang cukup besar bagi Pendapatan Asli Daerah. Pajak memiliki peran penting, selain berfungsi sebagai sumber pendapatan negara juga memiliki fungsi distribusi (pemerataan) pendapatan. Saat ini

\footnotetext{
${ }^{3}$ Ibid.
} 
konsumen sudah cukup dibebani dengan berbagai jenis pajak saat pembelian kendaraan baru. Mulai dari Pajak Penghasilan orang pribadi yang merupakan salah satu instrumen dalam rangka mengatasi kesenjangan distribusi pendapatan antara orang (masyarakat) yang memiliki penghasilan tinggi dan yang memiliki penghasilan rendah. Oleh karena itu, tarif Pajak Penghasilan pribadi di Indonesia mengenal tarif pajak progresif dimana semakin tinggi penghasilan maka semakin tinggi pula tarif Pajak Penghasilannya.

Pajak progresif adalah tarif pemungutan pajak dengan persentase yang naik dengan semakin besarnya jumlah yang digunakan sebagai dasar pengenaan pajak, dan kenaikan persentase untuk setiap jumlah tertentu setiap kali naik. ${ }^{4}$

Alasan teoritis pengenaan Pajak Kendaraan Bermotor (PKB) adalah penggunaan jalan raya yang merupakan barang publik oleh masyarakat. Penggunaan jalan raya menimbulkan biaya langsung dan tidak langsung. Saat ini konsumen sudah cukup dibebani dengan berbagai jenis pajak saat pembelian kendaraan baru. Mulai dari Pajak Pertambahan Nilai (PPN), Pajak Penjualan Barang Mewah (PPnBM), Pajak Kendaraan Bermotor (PKB). Untuk kendaraan import dikenakan pajak tambahan berupa bea masuk dan PPN Import. Kini dalam Undang-Undang Nomor 28 Tahun 2009 tentang Pajak Daerah dan Retribusi Daerah, tarif Pajak Kendaraan Bermotor dikenakan secara progresif, yakni $2 \%$ terhadap nilai jual untuk pembelian kendaraan bermotor pertama dan 2-10\% terhadap kendaraan kedua dan seterusnya. Pemerintah harus berhati-hati dalam mengeluarkan kebijakan tersebut dan mempertimbangkan apakah kebijakan ini sudah sesuai dengan asas-asas pemungutan pajak. Berbagai cara yang dilakukan pemerintah untuk meningkatkan peranan masyarakat dalam bidang

4 Mardiasmo, Perpajakan (Edisi Revisi 2013), Yogyakarta: CV. Andi Offset, 2013, HIm. 9. perpajakan adalah melakukan pembaharuan pajak atau lebih dikenal dengan reformasi perpajakan. Melalui reformasi perpajakan diharapkan mampu meningkatkan peranan masyarakat dalam bidang perpajakan. Dengan adanya sistem pemungutan pajak yang baru yaitu self assessment, pemerintah mengharapkan penerimaan pemerintah dari sektor pajak bisa meningkat melalui peningkatan kepatuhan wajib pajak. Pajak sebagai satu perwujudan kewajiban kenegaraan, ditegaskan bahwa penempatan beban kepada rakyat seperti pajak, retribusi dan lain-lain, harus ditetapkan dengan undangundang.

Pendapatan Asli Daerah yang antara lain berupa Pajak Daerah dan Retribusi Daerah, menjadi salah satu sumber pembiayaan dalam penyelenggaraan pemerintahan dan pembangunan daerah dalam rangka meningkatkan dan memeratakan kesejahteraan masyarakat. Dengan demikian daerah mampu melaksanakan otonomi, yaitu mampu mengatur dan mengurus rumah tangganya sendiri. Pajak Daerah dan Pajak Nasional, merupakan suatu sistem perpajakan Indonesia, yang pada dasarnya merupakan beban masyarakat sehingga perlu dijaga agar kebijaksanaan tersebut dapat memberikan beban yang adil bagi seluruh masyarakat. Sejalan dengan sistem perpajakan nasional, pembinaan pajak daerah dan retribusi daerah dilakukan secara terpadu dengan pajak nasional. Terutama mengenai objek dan tarif pajak, sehingga antara Pajak Nasional dengan Pajak Daerah dan Retribusi Daerah, saling melengkapi. Era otonomi daerah secara resmi berlaku di Indonesia sejak 1 Januari 2007 sehingga daerah dituntut mencari berbagai alternatif sumber penerimaan yang dapat digunakan membiayai pengeluaran atau belanja daerah. Pemberian kewenangan kepada daerah untuk memungut pajak dan retribusi daerah diperlukan adanya landasan hukum yang merupakan dasar hukum pungutan Pajak Daerah dan Retribusi Daerah yaitu 
Undang-Undang Nomor 28 Tahun 2009 tentang Pajak Daerah dan Retribusi Daerah. $^{5}$ Peranan pajak dirasa sangat penting, sehingga setiap tahun target penerimaannya harus ditingkatkan.

Dengan perubahan Undang-undang Pajak Daerah dan Retribusi Daerah Tahun 2009 memberikan kewenangan kepada daerah untuk memungut 11 (sebelas) jenis pajak yaitu 4 (empat) jenis pajak untuk tingkat provinsi dan 7 (tujuh) jenis pajak untuk tingkat kabupaten/kota. Namun kabupaten/kota masih diberi wewenang untuk menetapkan jenis pajak lainnya dengan syarat memenuhi ketentuan yang ditetapkan dalam undang-undang. Sedangkan dalam pemungutan retribusi, undang-undang mengatur proses penetapan jenis retribusi yang dapat dipungut daerah. Pemerintah provinsi maupun kabupaten/kota juga diberikan kewenangan menetapkan jenis retribusi selain yang ditetapkan dengan peraturan pemerintah.

Telah disampaikan bahwa UndangUndang Pajak Daerah dan Retribusi Daerah diadakan perubahan, adapun atas perubahan undang-undang dengan dasar pertimbangan: 6

1. Hasil penerimaan pajak dan retribusi belum memadai dan masih memiliki peran yang relatif kecil terhadap Anggaran Pendapatan Belanja Daerah (APBD).

2. Pemberian peluang untuk mengenakan pungutan baru yang diharapkan dapat meningkatkan penerimaan daerah dan kriteria yang ditetapkan dalam undang-undang hampir tidak ada jenis pungutan pajak dan retribusi baru yang dapat dipungut di daerah.

3. Pungutan baru yang ditetapkan daerah memberikan dampak negatif terhadap iklim investasi, sehingga menimbulkan ekonomi biaya tinggi sebagai akibat tumpang tindihnya dengan

5 Waluyo, Perpajakan Indonesia, Edisi 10, Jakarta: Salemba Empat, 2011, Hlm. 235.

6 Ibid., Hlm. 236. pungutan pusat dan menghalangi arus barang dan jasa antar daerah.

4. Tidak ada kewenangan provinsi, sehingga provinsi tidak dapat menyesuaikan penerimaan pajaknya, sehingga menimbulkan ketergantungan provinsi yang tinggi terhadap dana alokasi pusat yang menimbulkan pungutan retribusi baru yang bertentangan dengan Undang-Undang Pajak Daerah dan Retribusi Dearah.

5. Pengaturan kewenangan perpajakan dan retribusi yang ada kurang mendukung pelaksanaan otonomi daerah.

Peranan pemerintah daerah dalam penyelenggaraan pemerintahan dan pembangunan serta pelayanan masyarakat dalam pelaksanaan otonomi daerah akan semakin meningkat, peningkatan peranan ini dilandasi dengan kemampuan daerah untuk mengelola secara optimal potensi daerahnya sendiri termasuk dalam pengelolaan sumber-sumber Pendapatan Asli Daerah (PAD) untuk membiayai belanja rutin dan belanja pembangunan yang ditetapkan setiap tahun dalam anggaran pendapatan belanja daerah.

Sumber pendapatan daerah terdiri atas Pendapatan Asli Daerah (PAD), dana perimbangan, dan lain-lain pendapatan daerah yang sah. Berdasarkan kewenangannya, pajak dapat dibedakan sebagai pajak pusat dan pajak daerah. Mengenai pajak daerah, peranannya sangat penting sebagai sumber pendapatan daerah dan sebagai penopang pembangunan daerah. Karena pajak daerah adalah salah satu sumber pendapatan asli daerah. Seiring dengan diberlakukannya tarif pajak progresif pada kendaraan bermotor, masyarakat merasa semakin terbebani karena biaya yang dikeluarkan untuk membayar pajak kendaraan semakin bertambah.

Pajak daerah memiliki peran penting dalam meningkatkan penerimaan disamping pajak pemerintah pusat. Pajak daerah memiliki berbagai jenis pajak mulai dari pajak provinsi hingga pajak kabupaten/kota. Pemungutan pajak daerah 
oleh pemerintah daerah provinsi maupun kabupaten/kota diatur oleh UndangUndang Nomor 28 Tahun 2009 tentang Pajak Daerah dan Retribusi Daerah. Jenis pajak daerah sebagaimana yang diatur dalam Undang-Undang Nomor 28 Tahun 2009 dibagi menjadi 2 (dua) bagian. Dari sekian banyak pajak daerah, salah satu jenis pajak yang sumber pendapatannya cukup besar adalah Pajak Kendaraan Bermotor. Seperti yang telah diatur di Pasal 1 angka 12 Undang-Undang Nomor 28 Tahun 2009.

Hal ini disebabkan karena pertumbuhan penggunaan kendaraan bermotor di Indonesia terus mengalami peningkatan tiap tahunnya. Dapat dilihat dari banyaknya masyarakat yang lebih memilih menggunakan kendaraan pribadi dari pada kendaraan umum dalam menjalankan aktivitas mereka tidak hanya itu banyak masyarakat yang memiliki kendaraan lebih dari satu sehingga pertumbuhan kendaraan bermotor terus mengalami peningkatan dan pertumbuhan kendaraan ini juga disebabkan karena begitu mudahnya masyarakat dalam memperoleh atau mendapatkan kendaraan bermotor yang mereka inginkan karena adanya sistem kredit yang diberikan oleh dealer kepada masyarakat. Oleh karena itu, perlu dilakukan upaya efektivitas dalam pemungutan pajak kendaraan bermotor untuk meningkatkan penghasilan asli daerah dalam membantu pembagunan daerah.

Sedangkan pelaksanaan pemungutan pajak kendaraan bermotor itu sendiri dipungut melalui kantor bersama Sistem Administrasi Manunggal Satu Atap (SAMSAT). Dalam pelaksanaan pemungutan Pajak Kendaraan Bermotor yang diselenggarakan oleh unit pelayanan Kantor Bersama SAMSAT ini melibatkan tiga instansi pemerintah, yaitu: Dinas Pendapatan Daerah, Polisi Republik Indonesia, dan PT. (Persero) Asuransi Kerugian Jasa Raharja. Dalam proses pencatatan dan pembayaran pajak kendaraan bermotor menggunakan Sistem
Administrasi Manunggal di Bawah Satu Atap (SAMSAT) dalam pengeluaran STNK, pembayaran Pajak, BBNKB (Bea Balik Nomor Kendaraan Bermotor) dan Sumbangan Wajib Dana Kecelakaan Lalu Lintas Jalan (SWDKLLJ) semuanya dilakukan dalam satu atap sehingga masyarakat mudah dalam memenuhi kewajibannya dalam membayar pajak kendaraan bermotor.

Namun, dalam proses pemungutan pajak kendaraan bermotor saat ini masih belum optimal karena masih rendahnya partisipasi masyarakat dalam pembayaran pajak kendaraan bermotor tepat waktu dapat disebabkan oleh banyak faktor antara lain seperti kurang giatnya aparat dalam melakukan penagihan dan sikap apatis dari masyarakat itu sendiri dalam membayar pajak, selain dari itu banyak wajib pajak yang berdomisili jauh dari Kantor SAMSAT sehingga sulit untuk menjangkau tempat tersebut. Mengingat jumlah kendaraan yang terus meningkat setiap tahunnya sehingga dalam pemungutan pajak kendaraan bermotor harus lebih diefektifkan lagi terutama dalam penagihan pajak kendaraan bermotor.

Penerapan pengenaan tarif pajak progresif di Kota Bogor dan Kabupaten Bogor diharapkan bisa menekan volume kendaraan dan mengurangi angka kemacetan yang disebabkan padatnya kendaraan bermotor pribadi. Dengan pajak ini, pemilik kendaraan pribadi membayar pajak lebih mahal untuk pemilikan kendaraan kedua dan selanjutnya. Alasan teoritis pengenaan Pajak Kendaraan Bermotor (PKB) adalah penggunaan jalan raya yang merupakan barang publik oleh masyarakat. Penggunaan jalan raya menimbulkan biaya langsung dan tidak langsung. Saat ini konsumen sudah cukup dibebani dengan berbagai jenis pajak saat pembelian kendaraan baru. Mulai dari Pajak Pertambahan Nilai (PPN), Pajak Penjualan Barang Mewah (PPnBM), Pajak Kendaraan Bermotor (PKB). Untuk kendaraan import dikenakan pajak 
tambahan berupa bea masuk dan PPN Import. $^{7}$

Jika mengacu pada Pasal 6 ayat (2) Undang-Undang Republik Indonesia Nomor 28 Tahun 2009 tentang Pajak Daerah dan Retribusi Daerah, kepemilikan kendaraan bermotor didasarkan atas nama dan/atau alamat yang sama. Akan tetapi dalam Undang-Undang tersebut tidak ada penjelasan terhadap "penguasaan" yang dimaksud dalam definisi pajak kendaraan bermotor. Tidak jarang ada yang menafsirkan bahwa yang dimaksud menguasai kendaraan bermotor adalah orang atau badan yang memiliki kendaraan bermotor tersebut. Akan tetapi tidak sedikit yang menafsirkan bahwa yang dimaksud menguasai dilihat dari Bukti Kepemilikan Kendaraan Bermotor (BPKB) dan Surat Tanda Nomor Kendaraan (STNK). Hal ini tidak akan menimbulkan masalah jika saja pemerintah dapat melakukan sosialisasi dengan baik kepada masyarakat. Pemerintah harus berhati-hati dalam mengeluarkan kebijakan tersebut dan mempertimbangkan apakah kebijakan ini sudah sesuai dengan asas-asas pemungutan pajak. ${ }^{8}$

Berlakunya penerapan pajak progresif atas pajak kendaraan bermotor menimbulkan dampak bagi masyarakat, baik itu dampak positif maupun dampak negatif. Dampak positif dari diberlakukannya pajak progresif kendaraan bermotor ini diantaranya dapat menekan lonjakan jumlah kendaraan bermotor. Sedangkan bagi pemerintah daerah, dengan berlakunya pajak progresif untuk kendaraan bermotor menyebabkan bertambahnya jumlah pendapatan daerah

7 “Analisis Pengenaan Tarif Pajak Progresif Pada Pajak Kendaraan Bermotor Berdasarkan The Four Maxims", http://journal.unesa.ac.id/jurnal/jurnalakuntansi/artikel/739/analisis-pengenaan-tarifpajak-progresif-pada-pajak-kendaraan-bermotorberdasarkan-the-four-maxims. Diakses pada tanggal 22 Agustus 2016.

8 Fajariani, Analisis Dampak Pengenaan Tarif Pajak Progresif Pada Pajak Kendaraan Bermotor Berdasarkan The Four Maxims, Jurnal Akuntansi Unesa Volume 1, 2013, Hlm. 3. dari sektor pajak daerah. Dampak negatif yang terjadi dalam masyarakat yaitu masyarakat sebagai wajib pajak melakukan penyelundupan hukum untuk menghindari pembayaran pajak kendaraan bermotor yang lebih besar. Artinya seseorang yang memiliki kendaraan lebih dari satu dapat mengatasnamakan keluarganya ataupun pihak lain agar terhindar dari pajak progresif. 9

Sebagai contoh permasalahan yang penulis dapatkan dari koran Radar Bogor tanggal 12 Maret 2016. Si A sebagai pemilik motor $\mathrm{X}$ yang menjual kendaraan tersebut kepada B dengan cara yang sah. Akan tetapi, B belum mengurus balik nama motor X tersebut. Secara praktik, telah terjadi peralihan hak terhadap kepemilikan motor $\mathrm{X}$ tersebut. Akan tetapi, secara hukum masih belum terjadi peralihan hak terhadap kepemilikan motor $\mathrm{X}$ itu, sehingga secara hukum pemilik sah dari motor $\mathrm{X}$ adalah si A karena belum terjadi balik nama atas bukti kepemilikannya. Saat A akan membayar pajak motornya yang lain, motor Y, ternyata si A terkena pajak progresif kendaraan bermotor terhadap kepemilikan motor $\mathrm{X}$ yang secara praktik motor itu telah dijual kepada B.

Seiring dengan diberlakukannya pajak progresif tersebut, banyak masyarakat yang tidak nyaman dengan adanya penerapan pajak progresif tersebut sehingga banyak yang bertanya kenapa mereka membayar lebih banyak dari yang seharusnya. Hal ini disebabkan karena masyarakat tidak mendapatkan informasi yang jelas dan detail mengenai pengenaan pajak progresif kendaraan bermotor ini.

Berdasarkan uraian di atas, maka penulis tertarik menyusun Tesis dengan judul: EFEKTIFITAS PAJAK PROGRESIF KENDARAAN RODA DUA PADA SISTEM

9 Harist Agung Nugraha, “Penerapan Pajak Progresif Terhadap Wajib Pajak Kendaraan Bermotor Berdasarkan Peraturan Daerah Jawa Timur Nomor 9 Tahun 2010 tentang Pajak Daerah (Studi di Kantor bersama SAMSAT Malang Kota)", Skripsi, Malang: Program Sarjana Fakultas Hukum Universitas Brawijaya Malang, 2012. HIm. 12. 
ADMINISTRASI MANUNGGAL SATU ATAP (SAMSAT) KOTA BOGOR DAN KABUPATEN BOGOR.

Berdasarkan uraian latar belakang penelitian di atas, maka dapat diidentifikasi masalah sebagai berikut:

1. Bagaimana efektifitas pelaksanaan pajak progresif kendaraan roda dua pada SAMSAT Kota Bogor dan Kabupaten Bogor?

2. Bagaimana kendala dan upaya yang dilakukan pemerintah daerah untuk mengatasi penerapan pajak progresif kendaraan roda dua pada SAMSAT Kota Bogor dan Kabupaten Bogor?

3. Bagaimana solusi penerapan pajak progresif yang adil antara pemerintah dan wajib pajak?

\section{METODE PENELITIAN}

Metode penelitian yang digunakan dalam penelitian ini adalah pendekatan yuridis normatif, yaitu hukum dikonsepsikan sebagai norma, kaidah, asas atau dogma-dogma/yurisprudensi. Tahap penelitian yuridis normatif, menggunakan studi kepustakaan (penelaahan terhadap literatur).

\section{PEMBAHASAN}

\section{A. EFEKTIFITAS PELAKSANAAN PAJAK PROGRESIF KENDARAAN RODA DUA PADA SAMSAT KOTA BOGOR DAN KABUPATEN BOGOR}

\section{Berlakunya Pajak Progresif Terhadap Wajib Pajak Kendaraan Bermotor}

Pajak progresif untuk kendaraan bermotor mulai diberlakukan di Jawa Barat sejak Januari 2011. Berlakunya pajak progresif ini merupakan penerapan Pasal 6 Undang-Undang Nomor 28 Tahun 2009 tentang Pajak Daerah dan Retribusi Daerah yang pelaksanaannya ditetapkan dalam Peraturan Daerah Jawa Barat Nomor 13 Tahun 2011 tentang Pajak Daerah. Pajak progresif ini berlaku bagi kepemilikan kedua dan seterusnya kendaraan roda 4 (empat) atau lebih dan kendaraan roda 2 (dua).

Penetapan pajak progresif untuk pertama kali didasarkan pada urutan tanggal pendaftaran yang telah direkam pada database objek kendaraan bermotor atau pernyataan Wajib Pajak. Kepemilikan kendaraan bermotor oleh badan tidak dikenakan pajak progresif. Untuk selanjutnya apabila ada perubahan kepemilikan, wajib pajak harus melaporkan untuk merubah urutan kepemilikan.

Kepemilikan kendaraan bermotor untuk penetapan pajak progresif kendaraan bermotor didasarkan atas nama dan/atau alamat yang sama. Maksud dari pernyataan tersebut adalah nama dan/atau alamat yang sama dalam suatu keluarga yang dibuktikan dengan Kartu Susunan Keluarga (KSK) yang diterbitkan oleh instansi yang berwenang.

\section{Mekanisme Administrasi Pajak Kendaraan Bermotor}

Pelaksanaan penarikan pajak kendaraan sendiri dilakukan oleh Kantor Bersama SAMSAT yang diberikan kewenangan oleh Dinas Pendapatan Daerah di masing-masing daerah. Untuk wilayah Kota dan Kabupaten Bogor, penarikan pajak kendaraan bermotor dilaksanakan oleh Kantor Bersama SAMSAT Kota Bogor dan Kabupaten Bogor.

Pajak kendaraan bermotor ditetapkan berdasarkan perkalian dari dua unsur pokok, yaitu Nilai Jual Kendaraan Bermotor (NJKB) dan Bobot yang mencerminkan secara relatif tingkat kerusakan jalan dan/atau pencemaran lingkungan akibat penggunaan Kendaraan Bermotor. Pajak kendaraan bermotor ditetapkan berdasarkan perkalian dari dua unsur pokok, yaitu Nilai Jual Kendaraan Bermotor (NJKB) dan Bobot yang mencerminkan secara relatif tingkat kerusakan jalan dan/atau pencemaran lingkungan akibat penggunaan Kendaraan Bermotor.

Proses penghitungan penetapan pajak kendaraan bermotor ini biasanya terjadi jika wajib pajak mendaftarkan kendaraan 
baru yang dimiliki atau dikuasainya. Untuk proses pendaftaran kendaraan baru, wajib pajak harus memenuhi syarat yang telah ditetapkan. Syarat-syarat pendaftaran kendaraan baru tersebut yaitu menunjukkan KTP dan SIM asli beserta fotocopy (untuk perorangan), menyerahkan salinan akta pendirian, ket domisili, SK bermaterai yang ditandatangani oleh pimpinan dan cap badan hukum yang bersangkutan (Badan Hukum), faktur dari dealer, sertifikat uji tipe, Form. A (kendaraan Build-up), kendaraan yang berubah bentuk harus melampirkan SK dari karoseri yang telah mendapatkan ijin, dan SK bagi kendaraan umum yang telah memenuhi syarat. ${ }^{10}$

Setelah memenuhi syarat-syarat tersebut, wajib pajak harus mengikuti alur yang sesuai untuk mendapatkan penetapan dan pengesahan pajak. Demi mendapatkan pengesahan atau penetapan pajak, ada beberapa syarat yang harus dipenuhi oleh wajib pajak. Bagi wajib pajak perorangan, syarat tersebut yaitu menunjukkan KTP asli, BPKB asli, STNK asli, melakukan cek fisik, menunjukkan kwitansi pembelian materai dan Surat Keterangan (SK) dari Bank/Dealar/KOP/Gadai. Untuk wajib pajak yang berbentuk badan hukum, syarat yang dikenakan sama seperti wajib pajak perorangan namun ditambah dengan surat kuasa bermaterai yang ditandatangani oleh pimpinan dan cap badan hukum yang bersangkutan. ${ }^{11}$

\section{Penetapan Urutan Kepemilikan Kendaraan Bermotor}

Sejak Januari 2011, pajak progresif kendaraan bermotor memang telah diberlakukan tetapi sifatnya masih sosialisasi saja. Pada September 2011 hingga Desember 2011, wajib pajak diberi kesempatan untuk mengatur urutan kepemilikan kendaraan bermotornya. ${ }^{12} \mathrm{Hal}$

\footnotetext{
10 Data sekunder dari Kantor Bersama SAMSAT Kota dan Kabupaten Bogor yang didapat pada tanggal 12 September 2017.

11 Ibid.

12 Ibid.
}

ini merupakan salah satu cara yang diberikan oleh Kantor Bersama SAMSAT Kota dan Kabupaten Bogor untuk meringankan beban yang dikenakan bagi wajib pajak yang memang telah lebih dulu memiliki kendaraan lebih dari satu unit.

Setelah periode yang ditentukan di atas, pajak progresif kendaraan bermotor berjalan sesuai dengan peraturan perundang-undangan yang berlaku. Wajib pajak sudah tidak bisa mengatur urutan kepemilikan kendaraan bermotornya. Kepemilikan kendaraan bermotor itu sendiri ditetapkan berdasarkan tanggal wajib pajak memiliki kendaraan tersebut. ${ }^{13}$

\section{Penerapan Pajak Progresif Terhadap Wajib Pajak Kendaraan Bermotor}

Pengenaan pajak progresif ini tercantum dalam Pasal 7 Peraturan Daerah Jawa Barat Nomor 13 Tahun 2011 tentang Pajak Daerah. Adapun besarnya tarif pajak progresif tersebut adalah sebagai berikut:

1) Kepemilikan kedua sebesar 2,5\% (dua koma lima persen);

2) Kepemilikan ketiga sebesar 2,75\% (dua koma tujuh puluh lima persen);

3) Kepemilikan keempat sebesar $3,25 \%$ (tiga koma dua puluh lima persen);

4) Kepemilikan kelima dan seterusnya sebesar 3,75\% (tiga koma tujuh puluh lima persen).

Sebagaimana disebutkan sebelumnya, pajak progresif kendaraan bermotor dikenakan berdasarkan nama dan/atau alamat yang sama dalam satu keluarga. Sehingga wajib pajak yang memiliki kendaraan bermotor lebih dari satu unit melakukan balik nama terhadap kendaraan bermotor yang dimilikinya agar tidak terdaftar di database bahwa kendaraankendaraan tersebut ternyata dimiliki oleh satu individu saja.

Agar penerapan pajak progresif ini berjalan sesuai yang diharapkan, maka

13 Ibid. 
Kantor Bersama SAMSAT Kota dan Kabupaten Bogor memiliki petugas di lapangan yang bertugas untuk datang ke rumah wajib pajak yang terdarftar memiliki kendaraan bermotor pribadi lebih dari satu unit. Hal ini bertujuan untuk verifikasi apakah kendaraan tersebut masih dimiliki dan/atau dikuasai atau sudah berpindah ke orang lain.

Penerapan pajak progresif terhadap kendaraan bermotor ini diharapkan juga mampu meningkatkan Pendapatan Asli Daerah (PAD) Kota Bogor dan Kabupaten Bogor. Karena dengan meningkatnya jumlah pajak yang harus dibayarkan oleh wajib pajak, tentu saja berpengaruh terhadap PAD Kota Bogor dan Kabupaten Bogor.

\section{Dampak Berlakunya Pajak Progresif Kendaraan Bermotor}

Berlakunya pajak progresif menimbulkan dampak bagi masyarakat, baik itu dampak positif maupun dampak negatif. Dampak positif dari berlakunya pajak progresif kendaraan bermotor ini diantaranya berkurangnya jumlah kendaraan bermotor, terutama kendaraan roda dua. Sedangkan bagi pemerintah daerah, dengan berlakunya pajak progresif untuk kendaraan bermotor menyebabkan bertambahnya jumlah pendapatan daerah dari sektor pajak daerah. Dampak negatif yang terjadi dalam masyarakat yaitu masyarakat sebagai wajib pajak melakukan penyelundupan hukum.

\section{Pemberian Sanksi Terhadap Keterlambatan Pembayaran}

Denda yang dikenakan karena keterlambatan pembayaran pajak yaitu denda atas Pajak Kendaraan Bermotor dan denda atas SWDKLLJ. Kedua hal tersebut yang sebenarnya harus wajib pajak bayar tiap tahun. Apabila terlambat membayar 2 (dua) kategori pajak tersebut maka akan dikenakan denda yang cara perhitungannya sebagai berikut: ${ }^{14}$

1) Denda atas PKB, denda PKB adalah $25 \%$ dalam 1 (satu) tahun, apabila motor/mobil wajib pajak terlambat baru dalam 3 (tiga) bulan maka cara perhitungannya: PKB x 25\% $x$ (3/12), kalau 6 bulan, PKB x 25\% x (6/12), dan seterusnya.

2) Denda atas SWDKLLJ ini akan terlihat sama antara terlambat 3 (tiga) hari atau 1 (satu) tahun. Untuk Mobil ditetapkan dendanya sebesar 100.000,- sedangkan Motor dendanya sebesar 32.000.

3) Dengan catatan, denda PKB dihitung per tahun dan bulan tidak ditotalkan menjadi berapa bulan, sedangkan untuk sanksi SWDKLLJ dihitung per tahun.

\section{Pemberian Keringanan dan Insentif Pajak Daerah}

Penerapan pajak progresif terhadap wajib pajak kendaraan bermotor yang berlaku efektif setelah bulan Desember 2011, ternyata menimbulkan kenaikan terhadap jumlah denda yang dikenakan terhadap wajib pajak. Hal ini menyebabkan bertambahnya jumlah pajak kendaraan bermotor yang tidak dibayar oleh wajib pajak. Menanggapi hal tersebut, pemerintah provinsi sebagai pihak yang berwenang menangani pajak kendaraan bermotor mengaluarkan kebijakan yaitu dengan pembebasan denda pajak yang dikeluarkan melalui Peraturan Gubernur.

\section{B. KENDALA DAN UPAYA YANG DILAKUKAN PEMERINTAH DAERAH UNTUK MENGATASI PENERAPAN PAJAK PROGRESIF KENDARAAN RODA DUA PADA SAMSAT KOTA BOGOR DAN KABUPATEN BOGOR}

\footnotetext{
14 Hasil wawancara terhadap Kepala Bagian Pelaksana Pelayanan SAMSAT Kabupaten Bogor pada tanggal 11 September 2017.
} 
Kendala pemerintah daerah dalam mengatasi penerapan pajak progresif kendaraan roda dua pada SAMSAT Kota Bogor dan Kabupaten Bogor, yaitu:

1. Faktor Penghambat bagi Petugas yang Melakukan Pendataan Kendaraan Bermotor

Pada saat petugas mendata ke setiap rumah wajib pajak namun wajib pajak tersebut tidak ada di rumah. Hal ini menyebabkan petugas mengambil alternatif bertanya kepada tetangga dengan analisis dianggap mengetahui terhadap keadaan wajib pajak yang dimaksud oleh petugas. Metode ini tidak sedikit menimbulkan permasalahan, terutama jika kendaraan yang dimaksud oleh petugas yang mendata menurut tetangganya kendaraan tersebut sudah tidak pernah ada di rumah wajib pajak tersebut sehingga ditafsirkan bahwa kendaraan tersebut telah dijual oleh pemiliknya dan akhirnya dilakukan pemblokiran nomor kendaraan bermotor oleh petugas. ${ }^{15}$

\section{Faktor Sarana dan Prasarana}

Faktor yang menjadi penghambat lainnya dalam penerapan pembayaran pajak kendaraan bermotor yaitu tidak semua wajib pajak dapat membayarkan pajak kendaraan bermotornya pada jam kerja Kantor Bersama SAMSAT Kota dan Kabupaten Bogor karena mereka juga bekerja pada jam yang sama. Selain itu lokasi Kantor Bersama SAMSAT Kota dan Kabupaten Bogor juga cukup jauh dari tempat kerja mereka sehingga mereka harus meninggalkan pekerjaannya yang tentu saja membutuhkan waktu yang tidak sedikit agar sampai.

\section{Pajak \\ 3. Faktor Masyarakat Sebagai Wajib}

Faktor penghambat yang juga sering terjadi yaitu pengenaan pajak terhadap kendaraan yang ternyata telah dijual oleh pemilik pertama akan tetapi oleh pembeli belum terjadi balik nama sehingga

15 Hasil wawancara terhadap Kepala Administrasi Pelayanan di Kantor SAMSAT Kota Bogor, pada tanggal 11 September 2017. menyebabkan pemilik pertama tersebut terkena pajak progresif. Hal ini disebabkan, warga yang membeli kendaraan tersebut tidak langsung melakukan balik nama sehingga wajib pajak yang tidak memiliki kendaraan tersebut terpaksa masih harus membayar pajak kendaraan yang sudah tidak dikuasainya.

Untuk mengatasi kendala-kendala di atas, maka Samsat Kota dan Kabupaten Bogor melakukan beberapa usaha, yakni:

1. Menyangkut Kendala Intern yang terjadi di SAMSAT Kota dan Kabupaten Bogor.

Dengan memberikan pelatihan, seminar ataupun studi banding untuk Pegawai/Karyawan SAMSAT Kota dan Kabupaten Bogor untuk memperbaiki kualitas SDM dan menambah ilmu pengetahuan dan teknologi bagi Pegawai/Karyawan dalam rangka peningkatan kinerja kerja untuk memberikan pelayanan yang lebih baik pada masyarakat wajib pajak.

\section{Terkait Kendala Ekstern}

a. Dinas Pengelolaan Keuangan Daerah (DPKD) sebagai koordinator dan hanya menerima laporan realisasi pajak secara keseluruhan, sementara operasionalnya ada di masing-masing SAMSAT sudah seyogyanya pelaksanaan sistem E-KTP sudah dapat dimanfaatkan dan terealisasi bukan hanya di SAMSAT Kota dan Kabupaten Bogor guna untuk sistem pendataan yang akurat sehingga tidak ada lagi kerancuan dalan hal untuk keakuratan dan keabsahan data pribadi masing-masing wajib pajak yang tertanggung kewajibannya masing-masing.

b. Megenai ketidaktahuan masyarakat mengenai pelaksanaan tarif progresif pada pemungutan $\mathrm{PKB}$, pemerintah melakukan upaya-upaya sosialisasi mengenai tarif progresif pada PKB kepada masyarakat.

c. Untuk kendaraan yang diperjual-belikan hendaknya dilakukan proses balik nama untuk menghindari terkena tarif progresif. 


\section{SOLUSI PENERAPAN PAJAK PROGRESIF YANG ADIL ANTARA PEMERINTAH DAN WAJIB PAJAK}

Kantor Bersama SAMSAT Kota dan Kabupaten Bogor yang berwenang mengurus segala hal terkait pajak kendaraan bermotor, termasuk di dalamnya pajak progresif, tentu saja telah menyiapkan berbagai cara untuk meminimalisir berbagai permasalahan yang timbul dalam penerapan pajak progresif. Pihak Kantor Bersama SAMSAT Kota dan Kabupaten Bogor mengeluarkan inovasi dalam pelaksanaan pembayaran pajak kendaraan bermotor agar masyarakat menjadi lebih mudah dalam membayarkan pajak kendaraan bermotor mereka.

Untuk faktor sarana dan prasarana, memberikan pelayanan berupa yaitu adanya Samsat Corner, Samsat Drive Thru, dan Samsat Keliling. Selain itu warga dapat bertanya setiap saat terhadap hal-hal yang bersangkutan dengan pajak progresif kendaraan bermotor di Kantor Bersama SAMSAT Kota dan Kabupaten Bogor.

Untuk menyelesaikan kasus terkait kendaraan yang sudah dijual tapi belum dibalik nama, kepala pelaksana pelayanan di Kantor Bersama SAMSAT Kota dan Kabupaten Bogor mengatakan telah memberikan solusi yaitu, wajib pajak dapat melaporkan kepada SAMSAT untuk melakukan pemblokiran terhadap kendaraan yang telah dijual atau tidak lagi dimilikinya dengan cara apapun (waris, hibah, dll). Hal tersebut dinamakan pelayanan Lapor Jual, dan dengan adanya Lapor Jual dan pemblokiran nomor, maka data kepemilikan akan dihapus sehingga wajib pajak tidak perlu untuk membayar pajak kendaraan bermotor yang sudah tidak lagi dimilikinya. ${ }^{16}$ Karena telah diblokir, sehingga kewajiban membayar pajak terhadap kendaraan bermotor tersebut dikenakan kepada pihak yang telah membeli kendaraan bermotor tersebut dengan syarat harus mengajukan

16 Ibid. balik nama terhadap kendaraan yang telah dibelinya itu.

Sedangkan untuk faktor petugas di lapangan masih belum ada cara yang efektif untuk melakukan pendataan selain dengan yang dilakukan seperti sebelumnya. akan tetapi, saat ini sedang mencoba cara lain agar permasalahan tersebut tidak terjadi lagi.

\section{KESIMPULAN}

Berdasarkan uraian pada hasil penelitian dan pembahasan, maka penulis menarik kesimpulan sebagai berikut:

1. Pelaksanaan tarif pajak progresif kendaraan bermotor secara umum pada SAMSAT Kota Bogor dan Kabupaten Bogor belum optimal. Hal ini terlihat dari pendataan petugas di lapangan, serta masih banyaknya wajib pajak yang tidak aktif melaporkan tentang kepemilikan atau penjualan kendaraan bermotornya, sehingga terlihat dari realisasi tunggakan dari pajak kendaraan bermotor khususnya roda masih rendah pada SAMSAT Kota Bogor dan Kabupaten Bogor.

2. Bahwa faktor penghambat yang terjadi dalam penerapan pajak progresif terhadap Wajib Pajak Kendaraan Bermotor antara lain:

a. Faktor penghambat bagi petugas di lapangan;

b. Faktor Sarana dan Prasarana;

c. Faktor Masyarakat sebagai Wajib Pajak.

3. Untuk mengatasi kendala tersebut, upaya yang dilakukan oleh Kantor SAMSAT Kota Bogor dan Kabupaten Bogor adalah dengan melakukan evaluasi terhadap kendala-kendala yang ada dengan cara mencari solusi untuk mengatasi kendala yang dihadapi tersebut, serta dengan melakukan berbagai pelatihan bagi karyawan dan pegawai Kantor SAMSAT Kota Bogor dan Kabupaten Bogor demi untuk menumbuhkan dan mengembangkan kualitas Sumber Daya Manusia di 
lingkungan Kantor SAMSAT Kota Bogor dan Kabupaten Bogor. Di lain hal juga dengan melakukan penyuluhan dan sosialisasi kepada masyarakat akan pentingnya membayar pajak terutama pajak kendaraan bermotor.

4. Solusi dalam menghadapi kendala penerapan pajak progresif, yaitu:

1) Menambah sarana dan prasarana berupa SAMSAT Corner yang berada di Mall untuk mempermudah wajib pajak untuk melaksanakan kewajibannya membayar pajak kendaraan bermotornya.

2) SAMSAT melakukan jemput bola dengan SAMSAT Keliling agar wajib pajak yang terkendala waktu tetap dapat membayar pajak kendaraan bermotornya tepat waktu.

3) Kantor Bersama SAMSAT Kota Bogor dan Kabupaten Bogor juga mempermudah wajib pajak yang melakukan Lapor Jual terhadap kendaraan bermotor yang telah dijualnya agar wajib pajak tersebut tidak terkena pajak progresif. Pelayanang Lapor Jual ini bebas biaya atau gratis dan dengan waktu yang tidak lama.

\section{SARAN}

1. Berkaitan dengan penerapan pajak progresif terhadap wajib pajak kendaraan bermotor, diharapkan masyarakat yang membeli kendaraan bermotor, baik mobil maupun sepeda motor, untuk segera melakukan balik nama kendaraan bermotor agar pemilik kendaraan sebelumnya tidak dikenai pajak progresif terhadap kendaraan bermotor yang tidak dimilikinya lagi.

2. Berkaitan dengan faktor penghambat yang terjadi dalam pelaksanaan pajak progresif kendaraan bermotor, Kantor Bersama SAMSAT Kota Bogor dan Kabupaten Bogor dapat melakukan kegiatan SAMSAT keliling secara rutin dan terjadwal dan diharapkan penempatan armada di lokasi-lokasi yang strategis yang mudah dijumpai oleh wajib pajak yang ingin membayar pajak kendaraan bermotornya.

3. Adanya peningkatan dalam hal evaluasi dan peningkatan dalam menumbuh kembangakan kualitas Sumber Daya Manusia di jajaran Kantor SAMSAT Kota Bogor dan Kabupaten Bogor, agar semua target dan pencapaian dapat terlaksana dengan baik dan lancar.

\section{UCAPAN TERIMA KASIH}

\section{DAFTAR PUSTAKA}

\section{Buku:}

Mardiasmo, Perpajakan (Edisi Revisi 2013), Yogyakarta: CV. Andi Offset, 2013.

Syamsah, T.N., Kedudukan Pengadilan Pajak Dihubungkan Dengan Sistem Peradilan di Indonesia, Cetakan Pertama, Bogor: Unida Press, 2010.

Waluyo, Perpajakan Indonesia, Edisi 10, Jakarta: Salemba Empat, 2011.

\section{Peraturan Perundang-undangan}

Undang-Undang Dasar 1945. 
Undang-Undang Nomor 28 Tahun 2007 tentang Ketentuan Umum dan Tata Cara Perpajakan.

Undang-Undang Nomor 28 Tahun 2009 tentang Pajak Daerah dan Retribusi Daerah.

Peraturan Daerah Provinsi Jawa Barat Nomor 13 Tahun 2011 tentang Pajak Daerah.

\section{Jurnal, Skripsi}

Fajariani, Analisis Dampak Pengenaan Tarif Pajak Progresif Pada Pajak Kendaraan Bermotor Berdasarkan The Four Maxims, Jurnal Akuntansi Unesa Volume 1, 2013.

Harist Agung Nugraha, "Penerapan Pajak Progresif Terhadap Wajib Pajak Kendaraan Bermotor Berdasarkan Peraturan Daerah Jawa Timur Nomor 9 Tahun 2010 tentang Pajak Daerah (Studi di Kantor bersama SAMSAT Malang Kota)", Skripsi, Malang: Program Sarjana Fakultas Hukum Universitas Brawijaya Malang, 2012.

\section{Internet}

"Analisis Pengenaan Tarif Pajak Progresif Pada Pajak Kendaraan Bermotor Berdasarkan The Four Maxims", http://journal.unesa.ac.id/jurnal/jurnalakuntansi/artikel/739/analisis-pengenaan-tarif-pajak-progresif-pada-pajakkendaraan-bermotor-berdasarkan-the-four-maxims. Diakses pada tanggal 22 Agustus 2016. 